\title{
The Effect of Using Dictionary to Develop Students' Vocabulary in MTs. Al- Musthofa
}

\author{
Lisanul Uswa Sadieda \\ Faculty of Education \\ UIN Sunan Ampel Surabaya \\ Afik Wildan Muzakie \\ Faculty of Education \\ UIN Sunan Ampel Surabaya
}

\author{
Renaldi Bimantoro \\ Faculty of Education \\ UIN Sunan Ampel Surabaya \\ Bagus T.A \\ Faculty of Education \\ UIN Sunan Ampel Surabaya
}

\author{
Risqi Putri Rahmawati \\ MTs Al-Musthofa \\ Mojokerto
}

\begin{abstract}
Learning vocabulary is not an easy thing because as EFL students, they possibly find some difficulties in the meaning of the words. To decrease the difficulty of learning vocabulary, they must find the meaning of the words in the dictionary. By using a dictionary, it may help the students understanding. This research used classroom action research to know the effects of the dictionary to develop students' vocabulary. In this research, there are three cycles to make the research systematical. The data were collected by using observation in the entire 7 grade. Five classes will be used as experimental and two classes will be control class. Learning vocabulary is a very good way to help the students, especially for EFL students. The results show that the offline dictionary does not give much impact on students' vocabulary.
\end{abstract}

\section{Keywords: vocabulary, EFL students, dictionary}

\section{INTRODUCTION}

Language is a global area that has specific areas which one of them is called the vocabulary. Vocabulary is not a skill in English but when we do not learn about the language we cannot reck. In language, vocabulary has the main role because vocabulary can be used in all language skills. Vocabulary is one important knowledge in a language that has a beneficial role for learners in increasing their language ability [1].

Vocabulary in language learning is very important and therefore it is needed to be taught to students. When some people learn about vocabulary, they automatically increasing their skills step by step because vocabulary is a tool to connect with all of the skills. According to Viera (2017) "vocabulary knowledge is an essential tool for any language skills" which can be used to comprehend both written and spoken text [8]. Vocabulary knowledge in the production of written texts: A case study on EFL language learners." By using vocabulary our understanding of the writing and speaking will be clear enough. In this case, writing and speaking skills always consists of words. Vocabulary focuses on the words, so that is why this is having an important role in all language skills. However, vocabulary is not only about to learn about the meaning of the words but we must also know about the function of the words when we must use the words in the good situation. If we know the meaning and the function of the words it can make people enjoy to express their ideas. While if the students are still confuse and have limitation on their vocabulary, it will make big problems. Based on the Viera cited in Min, Y.K (2017) if students have a good vocabularies knowledge in their mind, they can communicate easily, while without vocabulary knowledge, they cannot do effective communication [8].

From the explanation above, if someone still confuses about vocabulary it will affect to their speaking and writing ability. Speaking and writing skills always appear in every activity especially for the students. Not only that, if the students feel the vocabulary is difficult and always think harder, they can be not confident with their vocabulary. Every student has a different vocabulary knowledge in their mind because they have the limitation. Especially for the people as a foreign language that still have the limitation of vocabularies. As a foreign language, they still have difficulties in two aspects; meaning and function. Those are will be a common problem the students learn about English especially for vocabulary. There are other problems, according to Dellar H and Hocking D, Innovations, LTP states "if you spend most of your time studying grammar, your English will not improve very much. You will see most improvement if you learn more words and expressions [7]. There are a lot of students that feel afraid when they learn English because they think English is always focused only on grammar. It is not true, because every skill needs vocabulary.

Nowadays, students need to solve the problem of their difficulty when they learn about vocabulary. There are a lot of treatments for EFL students to decrease their misunderstanding when they learn about vocabulary. One of 
dictionary it may facilitate the student to find their unfamiliar words and that is why it is a good solution for the students.

\section{METHOD}

In this research, the researcher makes two research questions; (1) What is the impact of a paper dictionary to increase the students' vocabulary? (2) How is the students' enthusiasm when they use the dictionary in English?. The first question is very clear what does the researcher wants. As we know every method that the teacher use in the class always has an impact to the students, it also means that the researcher wants to know the paper dictionary will help the student to improve their vocabulary or not. The second question means when the student use their dictionary, what the students' feel after they already know the meaning? For this case, it is very important to know what they feel when they find the meaning. The participants of this research from two different class but at the same grade and the same level in MTs Al-Musthofa Mojokerto. There are 13 classes in the school and the researchers choose only two classes. The researchers choose $7 \mathrm{E}$ and $7 \mathrm{C}$ to help us collecting the data. The two-class will be the class control and experimental group. The experimental group will be from 7E class and the control group will be from $7 \mathrm{C}$.

and definition of Net Generation. The participants of research are 360 university students aged between 18 to 21 y.o In this research, the researcher collects the data by questionnaire, so that is why this research is called quantitative research. For the result, the researcher concludes that the dictionary is very helpful for them because dictionary as a tool to facilitate their unknown and most of them said the strategy that very helpful for them is dictionary consultation.

The second title is "The effect of vocabulary knowledge and dictionary use an EFL reading performance", by Zhifa Shen [6]. This research conducted by the researcher to investigate the effects of vocabulary knowledge and dictionary use on EFL reading performance. The settings of this research are 110 students in the second-year-non English major from three intact classes in Zhejiong Gongshang University who were from three different academic disciplines-sociology, statistics, and engineering management. The result showed that the dictionary will improve the students score on vocabulary size, specific vocabulary, and reading comprehension. The most effective dictionary from this research is an electronic dictionary because its easily to bring anywhere and anytime.

The third title is "The impact of using an electronic dictionary on vocabulary learning and retention of Iranian EFL learners" by Amirian and Heshmatifar [2]. The researchers made one focus of this research to investigate the effects of electronic dictionary on learning and long-term retention of the vocabulary of Iranian lower-intermediate EFL learners. For this research, the researchers explained the importance of using an electronic dictionary and empirical studies on dictionary use. 60 female students are studying at a public high school in Sabzerar, Iran and the researchers used OPS (Oxford Placement Test), this is called independent sample T-test. The result summed up by using electronic

\section{Pre-test}

The pre-test was done in the first meeting when the students do the teaching-learning process in the class. It measured the students' vocabulary skill when they fill the pretest. The pre-test is related with the students material so it helped them to fill it. The pre-test only have 15 questions multiple choice and each student must fill it and they do not miss it. The pre-test has a purpose to assess the students' basic knowledge or their understanding of the material in the test based on Hilton cited in Willis (2015) [3]. The result of pretest helps the researchers to collect the data with a short time, so that is why this is very helpful.

\section{Post-test}

This is different from the pre-test, the different aspect is on the time that the researchers divided the test to the students. The post-test is the test that has given to the students after they had already done got treatment from the researchers www.meriam-webster.com. This also has the purpose like the pre-test is to measure the students understanding about the vocabularies that they have already got in the class. The measurement is to know the differences score between the experimental group and the control group. From this test, the researchers can conclude if the treatment that has given to the students in experimental group works or not.

\section{Observation}


group got a big score more than the control group. When the two samples did the pre-test, the researchers conclude that all of the students feel confident with their answer. So, there are a lot of students always ask their friends about the answer and to decrease it, the researchers walk around to each student. meaning of the vocabulary. Another beneficial thing by doing the observation, it is will to know the difficulties of the students when they use their dictionary.

The third title is "The impact of using an electronic dictionary on vocabulary learning and retention of Iranian EFL learners" by Amirian and Heshmatifar. The researchers made one focus of this research to investigate the effects of electronic dictionary on learning and long-term retention of the vocabulary of Iranian lower-intermediate EFL learners. For this research, the researchers explained the importance of using an electronic dictionary and empirical studies on dictionary use. 60 female students are studying at a public high school in Sabzerar, Iran and the researchers used OPS (Oxford Placement Test), this is called independent sample Ttest. The result summed up by using electronic dictionary it may facilitate the student to find their unfamiliar words and that is why it is a good solution for the students.

\section{FINDINGS AND DISCUSSION}

\section{Findings}

This research conducted by doing pre-test and post-test to collect the data. Two classes will be participants. The first class is from VII E as an experimental class and the second class is from VII C. Firstly, the researchers do the pre-test in the two classes. The pre-test consists of 15 questions that the students must fill it and it related to the material. The researchers choose the vocabulary related to the material because the vocabulary is familiar to the students.

\section{Cycle 1}

In this cycle, the researchers do the planning process. This planning to make the researchers easily to get the data. The planning of this research is to do the pre-test. As we know, each student has different knowledge, especially for vocabulary knowledge. The pre-test conducts just once and not repeating twice or more. The pre-test is originally from the students' ability in their understanding of vocabulary meaning.

\section{Pre-Test}

There are two samples to collect the data. The first class is from the $7 \mathrm{E}$ as the experimental group. Before the experimental group get the treatment from the researcher, they will do the pre-test to measure the students' vocabulary knowledge of each student. Not only the experimental group that do the pre-test but the control group also do the pre-test. They will get the same question about the pre-test. From the table of the experimental and control group, the researchers find the differences in the score that the students got. The majority of the students have a similar ability to their vocabulary (see figure 1.1). In this case, the experimental

\begin{tabular}{|c|c|c|}
\hline \multirow{2}{*}{$\begin{array}{l}\text { Students' } \\
\text { Number }\end{array}$} & \multicolumn{2}{|c|}{ Result of Pre-Test } \\
\hline & Experimental Group & Control Group \\
\hline 1 & 10 & 8 \\
\hline 2 & 10 & 3 \\
\hline 3 & 9 & 7 \\
\hline 4 & 5 & 8 \\
\hline 5 & 8 & 8 \\
\hline 6 & 10 & 7 \\
\hline 7 & 8 & 5 \\
\hline 8 & 7 & 8 \\
\hline 9 & 12 & 2 \\
\hline 10 & 9 & 3 \\
\hline 11 & 12 & 9 \\
\hline 12 & 10 & 3 \\
\hline 13 & 8 & 6 \\
\hline 14 & 5 & 7 \\
\hline 15 & 11 & 9 \\
\hline 16 & 8 & 9 \\
\hline 17 & 10 & 9 \\
\hline 18 & 10 & 8 \\
\hline 19 & 9 & 4 \\
\hline 20 & 7 & 6 \\
\hline 21 & 8 & 7 \\
\hline 22 & 9 & 7 \\
\hline 23 & 8 & 7 \\
\hline 24 & 11 & 6 \\
\hline 25 & 6 & 6 \\
\hline 26 & 9 & 5 \\
\hline 27 & 9 & \\
\hline 28 & 11 & \\
\hline 29 & 9 & \\
\hline 30 & 10 & \\
\hline
\end{tabular}

Figure 1.1 the result of pre-test

Cycle 2 


\begin{tabular}{|c|c|c|}
\hline 10 & 10 & 4 \\
\hline 11 & 13 & 10 \\
\hline 12 & 14 & 7 \\
\hline 13 & 6 & 7 \\
\hline 14 & 7 & 7 \\
\hline 15 & 8 & 8 \\
\hline 16 & 10 & 7 \\
\hline 17 & 7 & 9 \\
\hline 18 & 9 & 8 \\
\hline 19 & 12 & 4 \\
\hline 20 & 7 & 5 \\
\hline 21 & 7 & 5 \\
\hline 22 & 4 & 7 \\
\hline 23 & 7 & 3 \\
\hline 24 & - & 5 \\
\hline 25 & 7 & 5 \\
\hline 26 & 8 & 5 \\
\hline 27 & 7 & \\
\hline 28 & 11 & \\
\hline 29 & 9 & \\
\hline 30 & 10 & \\
\hline
\end{tabular}

After the researchers do the cycle 1 , the researchers move to cycle 2. In this cycle, the two samples have been divided. In the experimental group, the students will get the treatment for the researchers. The treatment is about vocabulary exercise in every meeting that has English schedule in that class. The treatment conducted by 10 vocabularies in every meeting. The researchers wrote the vocabularies in whiteboard then the students in the experimental group will write also in their notebook but the researchers give the time to the students to find the meaning of that vocabularies in their dictionary. Unfortunately, when the times are over the students still cannot find the meaning of all vocabularies. Sometimes they ask the researchers what the meaning of this word?

Another class is from the control group, the control group was not got a treatment. The students in that class also write the same vocabulary as the experimental group. The differences between the experimental group and control group are the students feel free to use or not the dictionary.

Cycle 3

After the experimental group got treatment for the researchers and the control group has done with their vocabulary in every meeting, then we go to the last cycle. The last cycle will do the post-test to know the dictionary gives a significant impact or not to increase the students' vocabulary. This test also same like pre-test, just do only once.

\section{Post-Test}

Post-test is the second test after the experimental group have already done with the treatment given by researchers. In the two classes have different students, in the experimental group, there are 30 students involved, but there is one student that not came to the class and for the control group, there are 26 students. The researchers hope that the dictionary will give significant impacts for the experimental group because they only get the treatment by the researchers. From the post-test there are a lot students that got a different score from the pretest (see figure 1.2).

\begin{tabular}{|c|c|c|}
\hline \multirow{2}{*}{$\begin{array}{c}\text { Students' } \\
\text { Number }\end{array}$} & \multicolumn{2}{|c|}{ Result of Post-Test } \\
\hline 1 & Experimental Group & Control Group \\
\hline 2 & 10 & 9 \\
\hline 3 & 10 & 6 \\
\hline 4 & 9 & 9 \\
\hline 5 & 8 & 10 \\
\hline 6 & 11 & 9 \\
\hline 7 & 9 & 8 \\
\hline 8 & 5 & 9 \\
\hline 9 & 10 & 9 \\
\hline
\end{tabular}

\section{Discussion}

Looking from the previous study that has done by Zhiva Shen (2013) The effects of vocabulary knowledge and dictionary use on EFL reading performance shows that the dictionary can improve the students' achievement on their score by vocabulary size, specific vocabulary, and reading comprehension [6]. The electronic dictionary is the most effective dictionary that has possibilities to help to improve the students' score because it's flexible and easy to bring everywhere and every time that the students' want. According to Nesi (2000) electronic dictionary is very easy to carry and a lot of people have already used it [5]. While this research wants to apply the experimental research into the junior high school of Al Musthofa. The experiment was applied into two groups that have different treatment. This research investigates the impact of using an offline dictionary to improve the students' vocabulary related to the topic in the class. The group one as an experimental group is Class E. Students in this class got intensive memorizing treatment with an offline dictionary. The second group as a control group is Class A. Students got discovery learning treatment with an offline dictionary. 
The results from post-test and pre-test score were counted. The average from the experimental group and the control group would show whether there are significant differences or not between the group that got a treatment or the group that was not got a treatment. Here is the equation to got the average of this data :

$$
\text { Average }=\frac{\text { The students'score in pre } / \text { post }}{\text { How many students do pre/post test }}
$$

After calculating the data, it shows that total scores from the experimental group are 268 from pre-test and 254 from post-test, the averages are 8,93 and 8,75 .

\section{Deviation $=$ the highest average - the lowest average}

The gap score from the pre-test and post-test is 0,18 . The scores from pre-test until post-test in the experimental group class were counted and its decreased, but the score was not significant. While the total scores from the control group are 167 from pre-test and 182 from post-test, the averages are 6,42 and 7,00. The gaps' score from the pre-test and post-test is 0,58 . The scores from pre-test until post-test in the control group class were increased. The results from pre-test and posttest found that the use of offline vocabulary did not give much impact on the experimental group, but the control group got an impact.

\section{CONCLUSION}

The research was classroom action research that took 2 classes from MTs Al-Musthofa as the control group and experimental group. The research used an offline dictionary as a tool to improve students' vocabulary in the class. The results found that the offline dictionary does not give much impact on experimental group class that has intensive memorizing treatment, but its impact on control group class that has no memorizing treatment. It can be concluded that the offline dictionary does not give an impact on students' vocabulary.

\section{REFERENCES}

[1] Alqahtani, Mofareh. (2015). The importance of vocabulary in language learning and how to be taught

[2] Amirian and Heshmatifar. (2013). The Impact of Using Electronic Dictionary on Vocabulary Learning and Retention of Iranian EFL Learners. Consortia Academia Publishing. Iran. Vol. 02 No. 01, pp 3544

[3] Hilton (2015). The importance of pretesting questionnaires : a field research example of cognitive pretesting the Exercise referral Quality of Life Scale (ER-QLS)

[4] Mokhtar, Ridwan, Sofan. (2013). The Role of Dictionary Strategy in Passive Vocabulary Knowledge Acquisition of Net Generation Students. Journal for the Study of Linguistic. Malaysia. Vol. 01 No. 01, pp 8-20. DOI : $10.5296 /$ jsel.v1i1.4444

[5] Nesi (2000). Electtronic Dictionaries In Second Language Vocabulary Comprehension and Acquisition: The State of the Art. Euralex. Warwick, UK. pp. 839-847
[6] Shen, Zhiva. (2013). The effects of vocabulary knowledge and dictionary use on EFL reading performance. Canadian Center of Science and Education. Vol 6, No. 6. pp 78-85. DOI : 10.5539/elt.v6n6p77

[7] Thornbury, Scott. How to teach vocabulary. pp. 13

[8] Viera, Rodrigo T. (2017). Vocabulary knowledge in the production of written texts : A case study on EFL language learners. Vol. 30, pp 89105 